\title{
Regulation of chitinase synthesis in Trichoderma harzianum
}

\author{
Cirano J. UlhoA and John F. Peberdy* \\ Department of Botany, Microbial Biochemistry and Genetics Group, University of Nottingham, \\ Nottingham NG7 2RD, UK
}

(Received 12 December 1990; revised 24 May 1991; accepted 3 June 1991)

\begin{abstract}
The production of chitinase by Trichoderma species is of interest in relation to their use in biocontrol and as a source of mycolytic enzymes. Fourteen isolates of the genus were screened to identify the most effective producer of chitinase. The best strain for chitinase was Trichoderma harzianum 39.1, and this was selected for study of the regulation of enzyme synthesis. Washed mycelium of $T$. harzianum 39.1 was incubated with a range of carbon sources. Chitinase synthesis was induced on chitin-containing medium, but repressed by glucose and $N$ acetylglucosamine. Production of the enzyme was optimal at a chitin concentration of $0.5 \%$, at $28{ }^{\circ} \mathrm{C}, \mathrm{pH} 6.0$ and was independent of the age of the mycelium. The synthesis of chitinase was blocked by both 8-hydroxyquinoline and cycloheximide, inhibitors of RNA and protein synthesis, respectively. The mode of chitinase synthesis in this fungus is discussed.
\end{abstract}

\section{Introduction}

Chitin, a $\beta$-1,4-linked polymer of $N$-acetylglucosamine, is a major component of the cell wall of many fungi (Austin et al., 1981; Peberdy, 1990). The enzymic degradation of chitin by micro-organisms occurs in two consecutive steps: first the hydrolysis by chitinase [poly(1,4-( $N$-acetyl- $\beta$-D-glucosaminide $))$ glycanohydrolase; EC 3 2.1.14] to oligomers, mainly dimers, followed by their degradation to free $N$-acetylglucosamine by chitobiase ( $N$-acetyl- $\beta$-glucosaminidase; EC 3.2.1.30). The monosaccharide released can then be metabolized by many organisms (Jeuniaux, 1966).

These enzymes are widely distributed in nature and have been detected in bacteria and fungi (Cabib, 1987). Fungal chitinases are involved in gross autolysis associated with the release of spores and stipe elongation in some basidiomycetes (Iten \& Matile, 1970) and autolysis of mycelium in cultures (Isaac \& Gokhale, 1982). They may have a nutritional role (de Vries \& Wessels, 1973) and a morphogenetic function in hyphal growth and differentiation of fungi (Bartnicki-Garcia, 1973; Burnett, 1979; Wessels, 1984).

In recent years several workers have suggested that chitinase-producing fungi, e.g species of Trichoderma, can be effective as biological control agents against fungal pathogens (Tokimoto, 1982; Chet, 1987). The main mechanism involved in the antagonism of Trichoderma spp. and pathogenic fungi appears to be the release of lytic enzymes, including chitinases.
Chitinases are produced by Trichoderma harzianum when it is grown in the presence of chitin or isolated fungal cell walls (Elad et al., 1983; Ridout et al., 1988; Tokimoto, 1982); however, other nutritional conditions that promote synthesis of this enzyme have not been investigated. Furthermore, it is not known whether the induction of chitinase by chitin in $T$. harzianum is effected by the same inducer-repressor mechanism as has been proposed for other hydrolases produced by Trichoderma strains (Merivuori et al., 1985). The objective of this study was to determine the physiological conditions which induce and repress chitinase production in $T$. harzianum.

\section{Methods}

Organism and culture conditions. All the Trichoderma strains used were from the University of Nottingham collection, except the Trichoderma hamatum strains (40.1, 40.2 and 40.3), which were obtained from Dr L. Maczinger, Department of Microbiology, Attila Jozsef University, Szeged, Hungary. Spores obtained from slant cultures on a malt/yeast/glucose agar medium ( $0.2 \%$ yeast extract, $0.2 \%$ malt extract, $2 \%$ glucose and $2 \%$ agar; all $\mathrm{w} / \mathrm{v}$ ) were collected in sterile water, centrifuged at 2000 r.p.m., washed twice and used as an inoculum $\left[1.0 \times 10^{7}\right.$ spores per $\mathrm{ml}$ of culture medium (TM)]. TM medium contained $\left(\mathrm{g} \mathrm{l}^{-1}\right)$ : bactopeptone, $1.0 ;$ urea, $0.3 ; \mathrm{KH}_{2} \mathrm{PO}_{4}, 2 \cdot 0$; $\left(\mathrm{NH}_{4}\right)_{2} \mathrm{SO}_{4}, 1 \cdot 4 ; \mathrm{MgSO}_{4} .7 \mathrm{H}_{2} \mathrm{O}, 0.3 ; \mathrm{CaCl}_{2} .6 \mathrm{H}_{2} \mathrm{O}, 0.3 ;$ and $0 \cdot 1 \%(\mathrm{v} / \mathrm{v})$ trace element solution containing $\mathrm{Fe}^{2+}, \mathrm{Mn}^{2+}, \mathrm{Zn}^{2+}$ and $\mathrm{Co}^{2+}$. The fungus was grown in conical flasks $(250 \mathrm{ml})$ containing $25 \mathrm{ml} \mathrm{TM}$ medium supplemented with the appropriate carbon source $(0.3-2.0 \%$, w/v) and incubated with shaking (180 r.p.m.) at $28^{\circ} \mathrm{C}$ for an appropriate time. 
Conditions for enzyme induction in washed mycelium. T. harzianum 39.1 was grown from a spore inoculum on TM medium using glucose $(2 \%, w / v)$ as the carbon source. The mycelium was harvested after $18-$ $24 \mathrm{~h}$ incubation, washed thoroughly with $250 \mathrm{ml} 10 \mathrm{~mm}$-potassium phosphate buffer $\mathrm{pH} 6.0$ and transferred to conical flasks containing $25 \mathrm{ml}$ minimal medium $\left(\mathrm{MM} ; \mathrm{KH}_{2} \mathrm{PO}_{4}, 2.0 \mathrm{gl}^{-1} ; \mathrm{MgSO}_{4} .7 \mathrm{H}_{2} \mathrm{O}, 0.3 \mathrm{~g}\right.$ $1^{-1}$; and $\left.\mathrm{CaCl}_{2}, 7 \mathrm{H}_{2} \mathrm{O}, 0 \cdot 3 \mathrm{~g} \mathrm{l}^{-1}\right)$. This was immediately supplemented with the substrates tested for their potential for induction. Mycelial suspensions were incubated with shaking ( 180 r.p.m.) at $28^{\circ} \mathrm{C}$ for up to $24 \mathrm{~h}$, unless stated otherwise.

Enzyme preparations. For chitinase production the mycelium was harvested by filtration onto Whatman no. 1 filter paper, washed with $250 \mathrm{ml} 10 \mathrm{~mm}$-potassium phosphate buffer, $\mathrm{pH} 6 \cdot 0$, frozen at $-70^{\circ} \mathrm{C}$ and freeze-dried. Lyophilized mycelium was weighed and then ground to a fine powder with liquid nitrogen. The samples were dialysed against $50 \mathrm{~mm}$-sodium acetate buffer $\mathrm{pH} 5.2$ and centrifuged at $12000 \mathrm{~g}$ for $15 \mathrm{~min}$ at $4{ }^{\circ} \mathrm{C}$. The supernatant was used as a soluble fraction and the pellet as the insoluble cell-bound fraction. The culture filtrate was dialysed overnight at $4{ }^{\circ} \mathrm{C}$ against 50 mM-sodium acetate buffer pH 5.2, stored at $-20^{\circ} \mathrm{C}$ and used as extracellular enzyme preparation.

Chitinase assay. The assay is based on the estimation of reducing sugars released during the hydrolysis of swollen chitin. The reaction mixture, containing $1 \mathrm{ml} 0.5 \%$ swollen chitin (suspended in $50 \mathrm{~mm}$ sodium acetate buffer $\mathrm{pH} 5 \cdot 2$, containing $0.02 \%$ sodium azide) and $1 \mathrm{ml}$ enzyme solution, was incubated for $1-24 \mathrm{~h}$ at $40^{\circ} \mathrm{C}$ with shaking, and then centrifuged at 4000 r.p.m. for $5 \mathrm{~min}$. The amount of reducing sugar released in the supernatant was determined by the method described by Miller (1959), using $N$-acetylglucosamine as standard. One unit (U) of activity was defined as the amount of enzyme which catalyses the release of $1 \mu \mathrm{mol}$ reducing sugar in $1 \mathrm{~h}$ at $40^{\circ} \mathrm{C}$. Specific activity is given in units (mg protein) ${ }^{-1}$.

Chitobiase activity. Chitobiase activity was determined by estimating the amount of $p$-nitrophenol released when enzyme preparations were incubated with $p$-nitrophenyl- $N$-acetyl- $\beta$-D-glucosamine. The reaction mixture comprised $0.2 \mathrm{ml} 5 \mathrm{mM}$-substrate, $0.7 \mathrm{ml} 10 \mathrm{mM}$-potassium phosphate buffer $\mathrm{pH} 6.0$, and $0.1 \mathrm{ml}$ enzyme solution. After $10 \mathrm{~min}$ at $37^{\circ} \mathrm{C}, 2.0 \mathrm{ml} 0.25 \mathrm{M}-\mathrm{Na}_{2} \mathrm{CO}_{3}$ was added to stop the reaction. The amount of $p$-nitrophenol liberated was measured spectrophotometrically at $405 \mathrm{~nm}$. One unit (U) of activity was defined as the amount of enzyme that liberates $1 \mu \mathrm{mol}$ of the reaction product from the substrate $\min ^{-1}$.

Enzyme purification. All operations were carried out at $4{ }^{\circ} \mathrm{C}$. Ammonium sulphate was added to the supernatant, from cultures grown on a chitin-containing medium, to give $75 \%$ saturation. The precipitate formed was collected by centrifugation and after dialysis (against $50 \mathrm{~mm}$-sodium acetate buffer $\mathrm{pH}$ 5.5: buffer A) was applied to a Q-Sepharose column $(1.6 \times 37 \mathrm{~cm})$ previously equilibrated with buffer $\mathrm{A}$. The chitinase which passed through the column in the void volume, was collected, concentrated by lyophilization and applied to a Sephadex G-100 column $(2.6 \times 92 \mathrm{~cm})$. The column was equilibrated and eluted with buffer $A$, at flow rate of $15 \mathrm{ml} \mathrm{h}^{-1}$. Fractions containing chitinase activity were pooled and applied to a PhenylSepharose CL-4B column $(1.5 \times 6.0 \mathrm{~cm})$ equilibrated with $10 \mathrm{mM}$ potassium phosphate buffer $\mathrm{pH} 6.7$, containing $0.8 \mathrm{M}$-ammonium sulphate. The column was washed with a linear gradient of $0.8-0 \mathrm{M}$ ammonium sulphate and active enzyme was eluted with a buffer solution containing no ammonium sulphate. Fractions showing chitinase activity were pooled and stored at $-70^{\circ} \mathrm{C}$.

Analytical methods. Mycelium was lyophilized overnight for dry weight determination. Protein concentration was determined by the method of Bradford (1976), using bovine serum albumin as standard. SDS-PAGE was carried out according to Laemmli (1970), using an
$11 \%(w / v)$ gel. Molecular mass markers were: bovine albumin $(66 \mathrm{kDa})$, egg albumin $(45 \mathrm{kDa})$, carbonic anhydrase $(29 \mathrm{kDa})$ and trypsin inhibitor $(20 \mathrm{kDa})$.

Reagents and chemicals. Size markers for electrophoresis, chitobiose, $p$-nitrophenyl- $N$-acetyl- $\beta$-D-glucosamine, cycloheximide, chitin and chitosan were commercial products from Sigma. 8-Hydroxyquinoline was purchased from FSA. Swollen chitin used in the chitinase assay was prepared from chitin by the method described Sneh (1981). All other chemicals used in the experiments were of the highest reagent grade.

\section{Results}

\section{Screening for extracellular chitinase and chitobiase production}

The Trichoderma strains were grown in TM medium, supplemented with $0.3 \%(\mathrm{w} / \mathrm{v})$ glucose and $0.5 \%(\mathrm{w} / \mathrm{v})$ chitin, at $28{ }^{\circ} \mathrm{C}$ and shaken at 180 r.p.m. After $48 \mathrm{~h}$ the cultures were harvested and protein, chitinase and chitobiase present in the culture filtrates were determined. All 14 Trichoderma strains tested produced chitinase and chitobiase when grown on chitin-containing medium supplemented with $0.3 \%(\mathrm{w} / \mathrm{v})$ glucose (Table 1). The best strains for chitinase production were T. harzianum 39.1 and Trichoderma sp. 41.4, which produced nearly 3-17 times more enzyme than any other strain. After $48 \mathrm{~h}$ the level of chitinase and chitobiase released to the medium was similar in both strains (Table 1). The kinetics of chitinase production are illustrated in

\section{Table 1. Screening for extracellular chitinase and chitobiase production by Trichoderma strains}

All strains were grown on TM medium supplemented with $0.3 \%$ glucose and $0.5 \%$ chitin and harvested after $48 \mathrm{~h}$ incubation. Each result is the mean of three replicates $\pm \mathrm{SD}$.

\begin{tabular}{|c|c|c|}
\hline \multirow[b]{2}{*}{ Strain* } & \multicolumn{2}{|c|}{$\begin{array}{l}\text { Specific activity } \\
{\left[\mathrm{U}(\mathrm{mg} \text { protein })^{-1}\right]}\end{array}$} \\
\hline & Chitinase & Chitobiase \\
\hline T. viride 37.1 & $0.49 \pm 0.23$ & $1.87 \pm 0.22$ \\
\hline T. viride 37.2 & $0.54 \pm 0.11$ & $3.34 \pm 0.06$ \\
\hline T. viride 37.3 & $0.64+0.02$ & $22.35+1.00$ \\
\hline T. viride 37.4 & $0.29 \pm 0.01$ & $14.29+0.46$ \\
\hline T. viride 37.5 & $0.30 \pm 0.01$ & $3.04 \pm 0.90$ \\
\hline$T$. aureoviride 38.1 & $0.28+0.01$ & $3 \cdot 28+0 \cdot 10$ \\
\hline T. harzianum 39.1 & $2.06 \pm 0.70$ & $8.67 \pm 0.83$ \\
\hline T. hamatum 40.1 & $0.37 \pm 0.05$ & $2.93 \pm 0.14$ \\
\hline T. hamatum 40.2 & $0.38+0.01$ & $5 \cdot 16+0.45$ \\
\hline T. hamatum 40.3 & $0.59 \pm 0.06$ & $17.74 \pm 0.60$ \\
\hline Trichoderma sp. 41.1 & $0.20 \pm 0.02$ & $36.88 \pm 0.60$ \\
\hline Trichoderma sp. 41.2 & $0.12+0.04$ & $0.95+0.01$ \\
\hline Trichoderma sp. 41.3 & $1.33 \pm 0.09$ & $1.84 \pm 0.02$ \\
\hline Trichoderma sp. 41.4 & $2 \cdot 00 \pm 0 \cdot 10$ & $9.26 \pm 0.40$ \\
\hline
\end{tabular}

* The strain numbers are those of the University of Nottingham collection. 


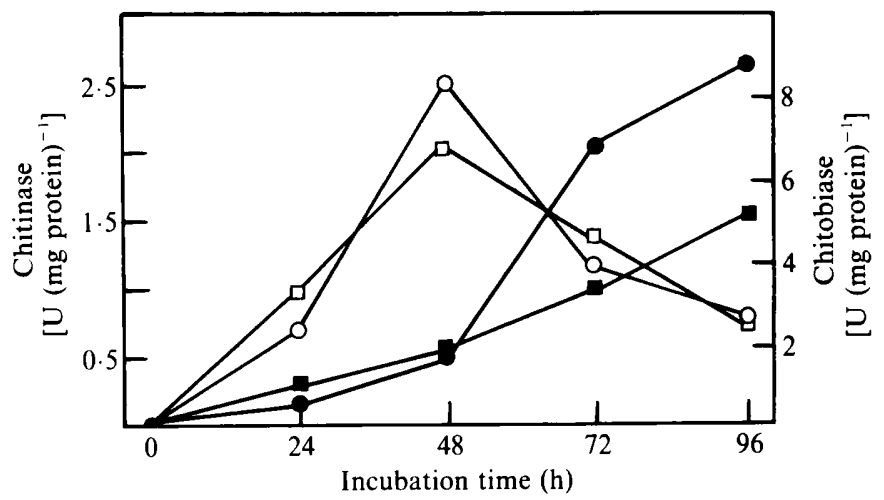

Fig. 1. Specific activity of chitinase $(O, \square)$ and chitobiase $(\boldsymbol{O}, \boldsymbol{\square})$ produced by $T$. harzianum $39.1(\mathrm{O}, \mathrm{O})$ and Trichoderma sp. $41.1(\square$, $\square$ ) during growth in liquid TM medium containing chitin as carbon source.

Table 2. Effect of different carbon sources on growth, extracellular protein and chitinase production by

\section{T. harzianum 39.1}

All cultures were inoculated with $10^{7}$ conidia $\mathrm{ml}^{-1}$ and harvested after $48 \mathrm{~h}$ incubation. Each result is the mean of three replicates \pm SD.

\begin{tabular}{|c|c|c|c|}
\hline Carbon source & $\begin{array}{c}\text { Growth } \\
\text { (mg dry wt) } \\
\text { per culture }\end{array}$ & $\begin{array}{c}\text { Protein } \\
\left(\mu \mathrm{g} \mathrm{ml}^{-1}\right)\end{array}$ & $\begin{array}{c}10 \times \\
\text { Chitinase } \\
\text { (U) }\end{array}$ \\
\hline Glucose $(0.3 \%)$ & $44 \cdot 0 \pm 1 \cdot 6$ & $13 \cdot 7 \pm 1 \cdot 1$ & $0.18 \pm 0.02$ \\
\hline Glucose $(0.5 \%)$ & $65 \cdot 4 \pm 2 \cdot 0$ & $12 \cdot 7 \pm 0.3$ & $0.24 \pm 0.02$ \\
\hline GlcNAc $(0.3 \%)$ & $15 \cdot 3 \pm 1 \cdot 5$ & $7.2 \pm 0.6$ & $0.08 \pm 0.01$ \\
\hline GlcNAc $(0.5 \%)$ & $43 \cdot 1 \pm 2 \cdot 0$ & $12.7 \pm 0.7$ & 0 \\
\hline GlcN $(0.3 \%)$ & $14 \cdot 5 \pm 1.0$ & $15 \cdot 4 \pm 1 \cdot 1$ & $0.29 \pm 0.03$ \\
\hline GlcN $(0.5 \%)$ & $34 \cdot 5 \pm 3 \cdot 5$ & $17.8 \pm 1.5$ & $0.37 \pm 0.02$ \\
\hline Sucrose $(0.3 \%)$ & $49 \cdot 2 \pm 2 \cdot 0$ & $9.4 \pm 0.5$ & $0.06 \pm 0.01$ \\
\hline Mannose $(0 \cdot 3 \%)$ & $40 \cdot 3 \pm 1 \cdot 7$ & $16.9 \pm 2 \cdot 1$ & $0.14 \pm 0.02$ \\
\hline Lactose $(0.3 \%)$ & $49 \cdot 3 \pm 1 \cdot 2$ & $7 \cdot 2 \pm 0.8$ & $\overline{0}$ \\
\hline Xylose $(0.3 \%)$ & $41 \cdot 3 \pm 1 \cdot 5$ & $16 \cdot 5 \pm 2 \cdot 8$ & $0.20 \pm 0.02$ \\
\hline Chitin $(0.5 \%)$ & ND & $20 \cdot 1 \pm 0 \cdot 2$ & $1.11 \pm 0.03$ \\
\hline Chitin $(1.0 \%)$ & ND & $34 \cdot 6 \pm 1 \cdot 3$ & $1.87 \pm 0.08$ \\
\hline
\end{tabular}

ND, Not determined.

* GlcNAc, $N$-acetylglucosamine; GlcN, glucosamine.

Fig. 1. Synthesis of chitinase increased rapidly after $24 \mathrm{~h}$, peaking at $48 \mathrm{~h}$; longer periods of culture resulted in an increase in extracellular chitobiase activity and a decrease in chitinase activity. $T$. harzianum 39.1 was selected for further studies on chitinase synthesis.

\section{Chitinase synthesis during growth on different carbon sources}

The synthesis of chitinase in the presence of its substrate raised the question of the regulation of synthesis. This was investigated using a range of alternative carbon sources (Table 2). Cultures were grown for $48 \mathrm{~h}$ under
Table 3. Effect of different carbon sources on the production of chitinase by washed mycelium of $T$. harzianum 39.1

Washed mycelium was incubated with the substrate for $24 \mathrm{~h}$ at $28^{\circ} \mathrm{C}$ and both cell-bound and extracellular chitinase were assayed. The results are means of three replicates \pm SD.

\begin{tabular}{|c|c|c|c|}
\hline \multirow[b]{2}{*}{ Carbon source* } & \multicolumn{3}{|c|}{$10^{3} \times$ Chitinase $\left[\mathrm{U}(\mathrm{mg} \text { mycelium })^{-1}\right]$} \\
\hline & Cell-bound & Extracellular & Total \\
\hline None & $0.33+0.03$ & $1.80 \pm 0.27$ & $2 \cdot 13 \pm 0.30$ \\
\hline Glucose $\left(10^{-2} \mathrm{M}\right)$ & $0.56 \pm 0.03$ & $1.67 \pm 0.29$ & $2.23 \pm 0.32$ \\
\hline GlcNAc $\left(10^{-2} \mathrm{M}\right)$ & $0.47 \pm 0.08$ & $1.39 \pm 0.28$ & $1.86 \pm 0.36$ \\
\hline Glucosamine $\left(10^{-2} \mathrm{M}\right)$ & $0.56 \pm 0.03$ & $2 \cdot 77 \pm 0 \cdot 28$ & $3 \cdot 33 \pm 0.31$ \\
\hline Sucrose $\left(10^{-2} \mathrm{M}\right)$ & $0.47 \pm 0.01$ & $2 \cdot 50 \pm 0 \cdot 28$ & $2.97 \pm 0.28$ \\
\hline Lactose $\left(10^{-2} \mathrm{M}\right)$ & $0.56 \pm 0.00$ & $3.88 \pm 0.28$ & $4.44 \pm 0.28$ \\
\hline Xylose $\left(10^{-2} \mathrm{M}\right)$ & $0.74+0.02$ & $3.05 \pm 0.25$ & $3.79 \pm 0.27$ \\
\hline Mannose $\left(10^{-2} \mathrm{M}\right)$ & $0.56 \pm 0.04$ & $3 \cdot 60 \pm 0 \cdot 28$ & $4 \cdot 16 \pm 0.32$ \\
\hline Cellobiose $\left(10^{-2} \mathrm{M}\right)$ & $0.45 \pm 0.03$ & $2.00 \pm 0.25$ & $2.45 \pm 0.28$ \\
\hline Chitobiose $\left(10^{-4} \mathrm{M}\right)$ & $0.60 \pm 0.01$ & $1.85 \pm 0.55$ & $2.45 \pm 0.56$ \\
\hline Chitin $(0.50 \%)$ & $1.50 \pm 0.05$ & $7 \cdot 20 \pm 0 \cdot 20$ & $8 \cdot 70 \pm 0.25$ \\
\hline S-chitin $(0.50 \%)$ & $2.70 \pm 0.25$ & $5 \cdot 30 \pm 0.25$ & $8.00 \pm 0.50$ \\
\hline Cellulose $(0.50 \%)$ & $0.20 \pm 0.05$ & $1.85 \pm 0.20$ & $2.05 \pm 0.25$ \\
\hline Chitosan $(0.50 \%)$ & $0.25 \pm 0.00$ & $0.50 \pm 0.01$ & $0.75 \pm 0.01$ \\
\hline
\end{tabular}

* GIcNAc, $N$-acetylglucosamine; S-chitin, swollen chitin.

conditions previously described, harvested and analysed for growth, extracellular protein and chitinase activity. Enzyme production was not related to mycelial biomass, as most of the non-inducing sugars supported good growth. However, high chitinase activities were found only in cultures supplied with chitin (Table 2). Biomass produced on chitin-containing medium was not determined, because of inaccuracies due to the mycelium being adsorbed onto chitin. Growth on $\mathrm{N}$-acetylglucosamine, at concentrations of 0.3 and $0.5 \%(\mathrm{w} / \mathrm{v})$, resulted in less enzyme production than was obtained with other non-chitinous substrates. In contrast, significant chitinase production, up to $20 \%$ of that of cultures grown on chitin, was observed in glucosamine-containing media (Table 2).

\section{Effect of various carbon substrates on the synthesis and secretion of chitinase in washed mycelium}

To verify the importance of chitin for chitinase induction an experimental system was used in which non-induced, glucose-grown mycelium was incubated in the presence of various carbon substrates. Washed mycelium was incubated in minimal medium supplemented with a range of other substrates for $24 \mathrm{~h}$ at $28^{\circ} \mathrm{C}$, and activities of cell-bound and extracellular chitinase were determined. Synthesis of the enzyme was influenced by the sugar used as a carbon source, but significant levels of chitinase were found when mycelium was incubated with chitin, with yields fourfold higher than on glucose (Table 3 ). This suggested that enzyme synthesis was induced by 


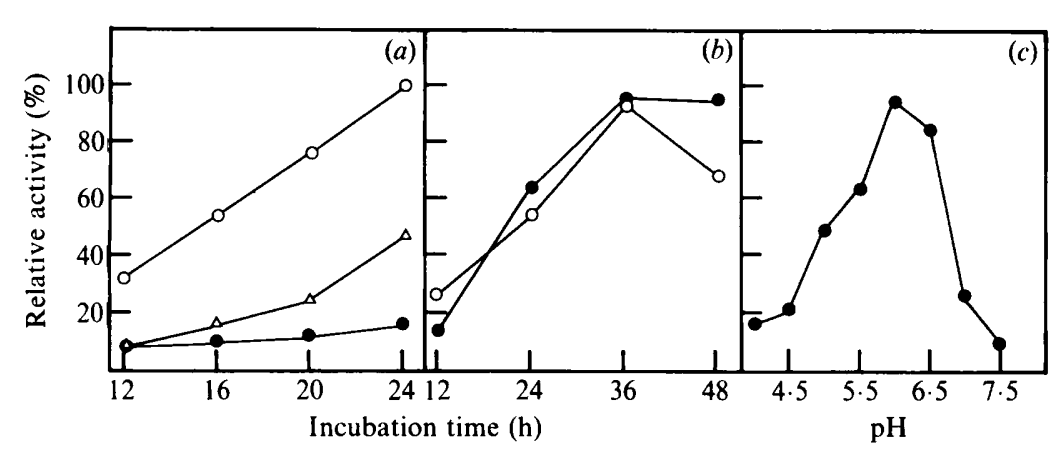

Fig. 2. Factors affecting chitinase production in washed mycelium of $T$. harzianum 39.1 : (a) temperature $\left(0,24^{\circ} \mathrm{C} ; \mathrm{O}, 28^{\circ} \mathrm{C} ; \triangle, 34^{\circ} \mathrm{C}\right) ;(b)$ mycelium age $(\mathrm{O}, 18 \mathrm{~h} ; 0,24 \mathrm{~h}) ;(c) \mathrm{pH}$.
Table 4. Influence of chitin concentration on the production of chitinase by washed mycelium of

\section{T. harzianum}

Washed mycelium was incubated with chitin for $18 \mathrm{~h}$ at $28^{\circ} \mathrm{C}$. Cell-bound and extracellular chitinase were assayed. The results are means of three replicates $\pm \mathrm{SD}$.

\begin{tabular}{lccr}
\hline \hline \multirow{2}{*}{$\begin{array}{c}\text { Chitin } \\
(\%)\end{array}$} & Cell-bound & Extracellular & \multicolumn{1}{c}{ Total } \\
\cline { 2 - 4 } & $2.4 \pm 0.2$ & $2.0 \pm 0 \cdot 1$ & $4.4 \pm 0.3$ \\
0 & $2.3 \pm 0.0$ & $18.0 \pm 0.9$ & $20.3 \pm 0.9$ \\
0.1 & $3.1 \pm 0.4$ & $24.0 \pm 1.2$ & $27.1 \pm 1.6$ \\
0.25 & $3.9 \pm 0.3$ & $35.0 \pm 0.9$ & $38.9 \pm 1 \cdot 2$ \\
0.5 & $3.7 \pm 0.3$ & $33.0 \pm 0.5$ & $36.7 \pm 0.8$ \\
1.0 & $2.9 \pm 0.1$ & $29.0 \pm 0.7$ & $31.9 \pm 0.8$ \\
2.0 & & & \\
\hline \hline
\end{tabular}

the substrate and the levels produced on glucose are constitutive. Clearly such a mechanism of control is not absolute because significant levels of production were obtained on lactose, xylose and mannose. Chitinase synthesis was repressed when other polymers such cellulose and chitosan were used as a substrate. Significant chitinase activity was present when the fungus was incubated in chitin-containing minimal medium, in the absence of any other compounds.

\section{Culture conditions for maximum chitinase synthesis in washed mycelium}

The production of chitinase in washed mycelium in chitin-containing medium was temperature dependent, levels detected at $28^{\circ} \mathrm{C}$ being higher than at $34^{\circ} \mathrm{C}$ and $24{ }^{\circ} \mathrm{C}$ (Fig. 2a). The physiological age of the mycelium was not a factor; both young and old mycelium, harvested at $18 \mathrm{~h}$ (linear phase) and $24 \mathrm{~h}$ (early stationary phase), respectively, showed similar production of extracellular chitinase (Fig. $2 b$ ). Production of chitinase was markedly affected by $\mathrm{pH}$, with the optimum at 6.0 (Fig. 2c). Chitinase production was substrate concentration dependent (Table 4 ); above $0.5 \%(\mathrm{w} / \mathrm{v})$ chitin there was no further promotion of synthesis.

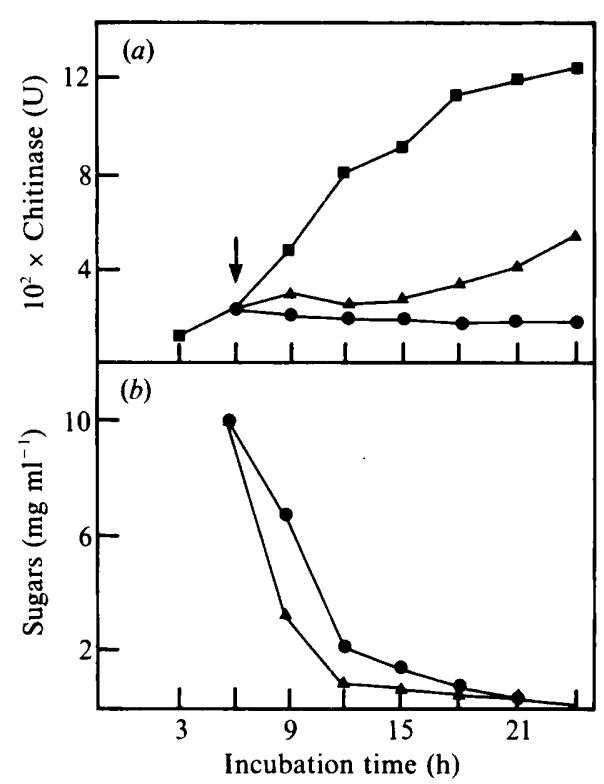

Fig. 3. Effect of glucose and $\mathrm{N}$-acetylglucosamine on the induction of chitinase in T. harzianum 39.1. (a) Washed mycelium was incubated with $0.5 \%$ chitin and after $6 \mathrm{~h}$ glucose ( $)$ or $N$-acetylglucosamine (O) was added to give a final concentration of $1 \%(w / v)$. The control $(\boldsymbol{D})$ contained no glucose or $N$-acetylglucosamine. (b) Concentrations of glucose $(\boldsymbol{\Delta})$ and $\mathrm{N}$-acetylglucosamine $(\boldsymbol{O})$ in the culture medium.

There was no appreciable accumulation of cell-bound chitinase before the appearance of the enzyme in the medium (Tables 3 and 4), indicating that synthesis and secretion of chitinase are closely associated events occurring only under conditions of favourable temperature and $\mathrm{pH}$.

\section{Effect of glucose and $\mathrm{N}$-acetylglucosamine on chitinase induction}

Experiments were carried out with washed mycelium in which chitin medium was supplemented with $1.0 \%(\mathrm{w} / \mathrm{v})$ glucose or $1.0 \%(\mathrm{w} / \mathrm{v}) \mathrm{N}$-acetylglucosamine at $0 \mathrm{~h}$ and $6 \mathrm{~h}$ of incubation. A decrease in chitinase production was observed in the presence of both carbon sources (Table 5, Fig 3). Repression was greatest when glucose or $\mathrm{N}$ - 


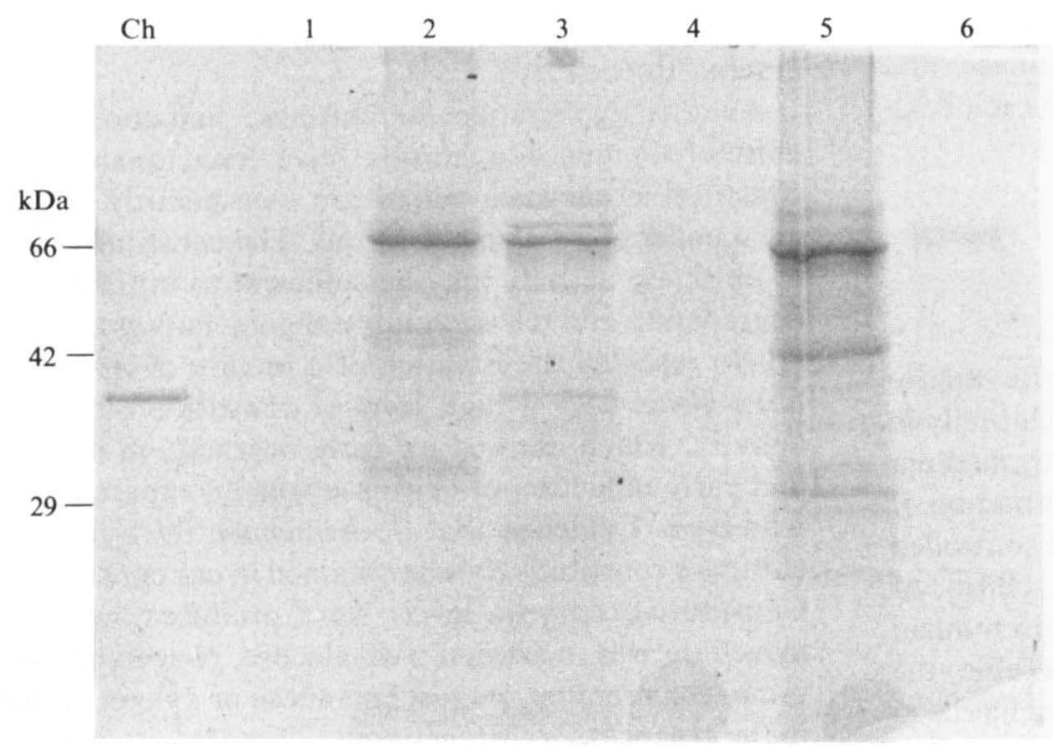

Fig. 4. SDS-PAGE analysis of proteins secreted by $T$. harzianum 39.1 after transfer of the mycelium from non-inducing conditions to media with different carbon sources: 1 , glucose $(1 \%) ; 2, N$-acetylglucosamine $(1 \%) ; 3$, chitin $(1 \%) ; 4$, chitin $(1 \%)+$ glucose $(1 \%) ; 5$, chitin $(1 \%)+N$-acetylglucosamine $(1 \%) ; 6$, GlcNAc $(1 \%)+$ glucose $(1 \%)$. Ch, chitinase purified from culture filtrate of $T$. harzianum. The sizes of marker proteins are shown on the left.
Table 5. Effect of single and mixed carbon sources on chitinase production by washed mycelium of $T$. harzianum 39.1

Each substrate or mixed substrate was added at onset of the experiment and cultures were harvested after $24 \mathrm{~h}$ incubation. All values are means of three replicates; standard deviations were less than $10 \%$ of the mean.

\begin{tabular}{lcc}
\hline \hline & \multicolumn{2}{c}{ Chitinase [U (mg protein) $\left.{ }^{-1}\right]$} \\
\cline { 2 - 3 } Carbon source* & Cell-bound & Extracellular \\
\hline Glucose $(1 \%)$ & 0.005 & 0.60 \\
GlcNAc $(1 \%)$ & 0.018 & 0.59 \\
Chitin $(0.5 \%)$ & 0.050 & 6.55 \\
Chitin $(0.5 \%)+$ Glucose $(1 \%)$ & 0.020 & 0.42 \\
Chitin $(0.5 \%)+$ GlcNAc $(1 \%)$ & 0.010 & 0.65 \\
GlcNAc $(1 \%)+$ Glucose $(1 \%)$ & 0.012 & 0.67 \\
\hline \hline
\end{tabular}

* GlcNAc, $N$-acetylglucosamine.

acetylglucosamine was added to the chitin-containing medium at the onset of the experiment. No induction could be detected and the level of chitinase activity was the same as that produced in the presence of $1.0 \%(\mathrm{w} / \mathrm{v})$ glucose or $1.0 \%(\mathrm{w} / \mathrm{v}) \mathrm{N}$-acetylglucosamine alone (Table $5)$. The proteins secreted into the culture filtrate were concentrated by precipitation with $75 \%$ saturation ammonium sulphate, separated by $11 \%$ SDS-PAGE gel and visualized by staining with Coomassie blue (Fig. 4). One protein band, with an apparent molecular mass of $40 \mathrm{kDa}$, was found only when chitin was used as carbon source. This protein has the same apparent molecular mass as purified chitinase from $T$. harzianum $(39.1 \mathrm{kDa}$; Fig. 4). In the presence of glucose and $N$-acetylglucosamine this protein band was not observed.
Table 6. The effect of inhibitors of RNA and protein synthesis on extracellular protein and chitinase activity in washed mycelium of T. harzianum 39.1.

\begin{tabular}{lcc}
\hline \hline $\begin{array}{l}\text { Inhibitor } \\
\left(\mu \mathrm{g} \mathrm{ml}^{-1}\right)\end{array}$ & $\begin{array}{c}\text { Protein } \\
\left(\mu \mathrm{g} \mathrm{m}^{-1}\right)\end{array}$ & $\begin{array}{c}10^{3} \times \text { Chitinase activity* } \\
{\left[\mathrm{U}\left(\mathrm{mg} \mathrm{mycelium}^{-1}\right]\right.}\end{array}$ \\
\hline $\begin{array}{l}\text { None } \\
\text { 8-Hydroxyquinoline }\end{array}$ & 21.4 & 8.02 \\
20 & 22.2 & 3.02 \\
50 & 21.5 & 2.50 \\
100 & 10.8 & 2.37 \\
Cycloheximide & & \\
5 & 13.9 & 1.05 \\
10 & 16.6 & 0.32 \\
20 & 17.7 & 0.39 \\
\hline \hline
\end{tabular}

* The results are means of two replicates.

Addition of the sugars $6 \mathrm{~h}$ after the onset of induction also repressed chitinase production (Fig. $3 a$ ). The rate of utilization of the two sugars was similar (Fig. 3b); exhaustion of glucose prompted the production of enzyme, but this was not observed with $N$-acetylglucosamine.

\section{Inhibition of RNA and protein synthesis and its effect on enzyme induction}

To determine whether the production and secretion of chitinase was dependent on de novo protein synthesis, the effects of 8-hydroxyquinoline and cycloheximide, which inhibit RNA and protein synthesis respectively (McKeehan \& Hardesty, 1969; Fraser \& Creanor, 1974), on chitinase production during induction were investigated. The results are shown in Table 6. Both inhibitors 
exhibited a strong effect on chitinase production in washed mycelium. The induction of chitinase and protein synthesis was supressed far more with cycloheximide than with 8-hydroxyquinoline.

\section{Discussion}

A wide range of prokaryotic and eukaryotic microorganisms have the potential to produce chitinolytic enzymes when chitin is present in the growth medium (Jeuniaux, 1966; Monreal \& Reese, 1969). Formation of chitinase in micro-organisms is thought to be controlled by a repressor-inducer system in which chitin or products of degradation (oligomers) serve as an inducer (Monreal \& Reese, 1969). Since chitin is insoluble, the micro-organisms are unable to utilize it unless it has been hydrolysed to soluble oligomers or $\mathrm{N}$-acetylglucosamine. Several proposals have been made to explain how induction may occur in this situation.

Monreal \& Reese (1969) suggested that the most probable inducers of chitinase in Serratia marcescens are soluble oligomers derived from chitin, but not the monomer ( $N$-acetylglucosamine). In contrast, St Leger $e t$ al. (1986), using slow-feeding with sugars or alanine in a carbon-deficient medium, demonstrated that the most effective inducer of chitinase in Metarhizium anisopliae was $N$-acetylglucosamine, when supplied at a rate of about $20 \mu \mathrm{g} \mathrm{ml}^{-1} \mathrm{~h}^{-1}$. Smith \& Grula (1983), working with Beauveria bassiana, reported that the sterilization of chitin by autoclaving or boiling causes release of glucosamine and $\mathrm{N}$-acetylglucosamine from the macromolecule and the solubilized components function as the inducers for chitinase synthesis. Roby et al. (1987) showed that some chitin oligomers (hexamer to nonamer), at high concentrations, enchanced chitinase activity in melon plants by a factor of 3 to 5 .

The work described in this paper shows that chitinase synthesis in $T$. harzianum 39.1 is also regulated by products of chitin degradation. High chitinase activity was found only in cultures supplied with chitin but not with other polymers such as cellulose and chitosan, which is further indicative of induction. Interestingly, removal of the acetyl group produces a non-susceptible substrate (chitosan) and substitution of the $\mathrm{N}$-acetyl group with $\mathrm{OH}$ (=cellulose) similarly yields a nonsubstrate. Neither chitobiose nor $N$-acetylglucosamine promoted enzyme production in T. harzianum 39.1 under the conditions of these experiments. The levels obtained were comparable with those produced with glucose. However, it seems unlikely that chitobiose could function as an inducer of chitinase activity since extracellular constitutive chitobiase activity would probably degrade chitobiose to $\mathrm{N}$-acetylglucosamine before it entered the cell.

Another explanation for chitinase induction is that chitinolytic micro-organisms have trace quantities of constitutive enzymes which are continuously released even under starvation conditions. The constitutive level of chitinase activity may be sufficient to initiate chitin degradation and release soluble oligomers. Vasseur et al. (1990) reported the isolation of a mutant of Aphanocladium album with a high level of constitutive chitinase activity, which allowed an early degradation of chitin and early induction of chitinase when compared to the wild-type. Evidence that $T$. harzianum 39.1 produces chitinase constitutively was obtained in our experiments. Constitutive enzyme levels were produced when the mycelium was incubated with glucose, $N$-acetylglucosamine, glucosamine, sucrose, mannose or xylose, or even in the absence of a carbon source. These results lead us to the view that the probable inducers of chitinase in $T$. harzianum 39.1 are soluble oligomers derived from the chitin preparation or by the action of constitutive chitinase.

Another possible suggestion, so far unsubstantiated, is that the signal for induction of synthesis of chitinase could result from the physical contact between the cell surface and the insoluble substrate, as has been proposed for cellulase biosynthesis (Berg \& Petterson, 1977; Binder \& Ghose, 1978).

The inductive formation of chitinase in washed mycelium of $T$. harzianum 39.1 was markedly affected by addition of glucose or $\mathrm{N}$-acetylglucosamine, suggesting that catabolic repression may be involved in the regulation of chitinase synthesis. The synthesis of various catabolic enzymes in micro-organisms is repressed when glucose or other readily metabolizable compounds are added to the culture. In Trichoderma viride (Nisizawa et al., 1972) and Trichoderma reesei (Merivouri et al., 1985) the formation of some hydrolases, including $\alpha$-amylase, $\beta$-glucosidase, xylanase and cellulase, was affected by glucose. This phenomenon has been called the glucose effect (Epps \& Gale, 1942), or catabolic repression (Neidhardt, 1960; Holzer, 1976). It appears that the formation of certain types of enzymes in fungi is affected by catabolic repression to varying degrees, irrespective of whether they are inducible or constitutive (Nisizawa et al., 1972).

Induction of chitinase was inhibited by addition of 8hydroxyquinoline and cycloheximide, suggesting that $d e$ novo transcription and translation are necessary for induction to occur.

C.J.U was supported by Conselho Nacional de Desenvolvimento Cientifico e Tecnologico, Brazil. We wish to thank D. R. West and J. B. Green for technical support, and B. V. Case for photographic work. 


\section{References}

Austin, R. R., Brine, C. J., Castle, J. E. \& Zikakis, J. P. (1981). Chitin: New facets of research. Science 212, 749-753.

BARTNICKI-GARCIA, S. (1973). Fundamental aspects of hyphal morphogenesis. In Microbial Differentiation, pp. 245-268. Edited by J. M. Ashworth \& J. E. Smith. Cambridge: Cambridge University Press.

BERG, B. \& PETTERSON, G. (1977). Location and formation of cellulases in Trichoderma viride. Journal of Applied Bacteriology 42, 65-75.

Binder, A. \& GHOSE, T. K. (1978). Adsorption of cellulose by Trichoderma viride. Biotechnology and Bioengineering 19, 1187-1199.

BRADFORD, M. M. (1976). A rapid and sensitive method for quantitation of microgram quantities of protein utilizing the principle of protein-dye binding. Analytical Biochemistry 72, 248254.

BURNETT, J. H. (1979). Aspects of structure and growth of hyphal wall. In Fungal Walls and Hyphal Growth, pp. 1-25. Edited by J. H. Burnett \& A. P. J. Trinci. Cambridge: Cambridge University Press.

CABIB, E. (1987). The synthesis and degradation of chitin. Advances in Enzymology 59, 59-101.

CHET, I. (1987). Trichoderma - application, mode of action and potential as a biocontrol agent of soilborne plant pathogenic fungi. In Innovative Approaches to Plant Disease Control, pp. 137-160. Edited by I. Chet. New York: Wiley.

Elad, Y., Chet, I., Boyle, P. \& Henis, Y. (1983). Parasitism of Trichoderma sp. on Rhizoctonia solani and Sclerotium rolfsii scanning electron microscopy and fluorescence microscopy. Phytopathology 73, 85-88.

EPPS, H. M. R. \& GALE, E. F. (1942). The influence of the presence of glucose during growth on the enzymic activities of Escherichia coli. Comparison of the effect with that produced by fermentation acids. Biochemical Journal 36, 619-623.

Fraser, R. S. S. \& Creanor, J. (1974). Rapid and selective inhibition of RNA synthesis in yeast by 8-hydroxyquinoline. European Journal of Biochemistry 46, 67-73.

Holzer, H. (1976). Catabolic inactivation in yeast. Trends in Biochemical Sciences 1, 178-181.

ISAAC, G. \& GoKhale, A. V. (1982). Autolysis: a tool for protoplast production from Aspergillus nidulans. Transactions of the British Mycological Society 78, 389-394.

ITEN, W. \& MATILE, P. (1970). Role of chitinase and other lysosomal enzymes of Coprinus lagopus in the autolysis of fruiting bodies. Journal of General Microbiology 61, 301-309.

Jeuniaux, C. (1966). Chitinases. Methods in Enzymology 8, 644-650.

LAEMmLI, U. K. (1970). Cleavage of structural proteins during the assembly of the head of bacteriophage T4. Nature, London 227, 680685.

McKeeham, W. \& HaRdesty, B. (1969). The mechanism of cycloheximide inhibition of protein synthesis in rabbit reticulocytes. Biochemical and Biophysical Research Communications 36, 625-630.
Merivouri, H., Siegler, K. M., Sands, J. A. \& Montenecourt, B. S. (1985). Regulation of cellulase biosynthesis and secretion in fungi. In Biochemical Society Transactions, pp. 411-414. Edited by D. C. Watts. London: The Biochemical Society.

Miller, G. L. (1959). Use of dinitrosalicylic acid reagent for determination of reducing sugars. Analytical Chemistry 31, 426-428.

Monreal, J. \& ReEse, E. T. (1969). The chitinase of Serratia marcescens. Canadian Journal of Microbiology 15, 689-696.

NeIDHARDT, F. C. (1960). Mutant of Aerobacter aerogenes lacking glucose repression. Journal of Bacteriology 80, 536-543.

Nisizawa, T., Suzuki, H. \& Nisizawa, K. (1972). Catabolite repression of cellutise formation in Trichoderma viride. Journal of Biochemistry 71, 999-1007.

Peberdy, J. F. (1990). Fungal cell walls. A review. In Biochemistry of Cell Walls and Membranes in Fungi, pp. 5-30. Edited by P. J. Kuhn, A. P. J. Trinci, M. J. Jung, M. W. Goosey \& L. G. Copping. London: Springer-Verlag.

Ridout, C. J., Coley-Smith, J. R. \& Lynch, J. M. (1988). Fractionation of extracellular enzymes from mycoparasitic strain of Trichoderma harzianum. Enzyme and Microbial Technology 10, 180 187.

Roby, D., Gadelle, A. \& Toppan, A. (1987). Chitin oligosaccharides as elicitor of chitinase activity in melon plants. Biochemical and Biophysical Research Communications 143, 885-892.

Smith, R. J. \& Grula, E. A. (1983). Chitinase is an inducible enzyme in Beauveria bassiana. Journal of Invertebrate Pathology 42, 319-326.

SNEH, B. (1981). Use of rhizosphere chitinolytic bacteria for biological control of Fusarium oxysporum f. sp. dianthi in carnation. Phytopathologische Zeitschrift 100, 251-256.

St Leger, R. J., Cooper, R. M. \& Charnley, A. K. (1986). Cuticledegrading enzymes of entomopathogenic fungi. Regulation of production of chitinolytic enzymes. Journal of General Microbiology 132, 1509-1517.

Tокімото, K. (1982). Lysis of the mycelium of Lentinus edodes caused by mycolytic enzymes of Trichoderma harzianum when the two fungi were in an antagonistic state. Transactions of the Mycological Society of Japan 23, 13-20.

Vasseur, V., ARigoni, F., ANDERsen, H., Defago, G., Bompeix, G. \& SENG, J.-M. (1990). Isolation and characterization of Aphanocladium album chitinase-overproducing mutants. Journal of General Microbiology 136, 2561-2567

DE VRIES, O. M. H. \& Wessels, J. G. H. (1973). Release of protoplasts of Schizophyllum commune by combined action of purified $\alpha-1,3-$ glucanase and chitinase derived from Trichoderma viride. Journal of General Microbiology 76, 319-330.

Wessels, J. G. H. (1984). Apical hyphal wall extension. Do lytic enzymes play a role? In Microbial Cell Wall Synthesis and Autolysis (FEMS Symposium 27), pp. 31. Edited by C. Nombela. Amsterdam: Elsevier. 